\title{
Research on Cultivation mode of Excellent Numerical Control Talents in Application-Oriented College
}

\author{
Hongmei Fan ${ }^{1, a}$ \\ ${ }^{1}$ School of Automation, Nanjing Institute of Technology, Nanjing 211167, China; \\ azdhxfhm@njit.edu.cn
}

Keywords: numerical control talents, cultivation mode, application oriented university.

\begin{abstract}
With the rapid development and comprehensive application of numerical control technology, demands of excellent talents in this field are increased to a great extent. Aiming at the defective traditional cultivation quality of numerical control talents, the cultivation target of numerical control talents for application-oriented colleges is presented. To realize this target, the cultivation mode reform both on theory course teaching and practical skill training is discussed. Based on utilizing the social resources better, the method of implementing school-enterprise cooperation is proposed, which provides reference for seamless cultivation of excellent numeric control talents.
\end{abstract}

\section{Introduction}

With the continuous development of science and technology, the application of numerical control technology in modem industry is more and more extensive. The numerical control technology will play an important role to the development of modem industry, especially to the underdevelopment countries[1]. A lot of manpower, material and financial resources are invested to develop numerical technology by developed countries. In china, with the development of economic, especially with the development of mechanical manufacturing industry, the demands of the numerical technology talents is increased sharply. Many colleges and universities set numerical control specialty, and cultivate many numerical control talents for the society.

At present, there are three kinds of colleges: 1) vocational college, which cultivates numerical control operator; 2) research-oriented college, which aims at training numerical control technology research and development person; 3) application-oriented college, according to the actual requirement of the society, target of this category should be cultivate interdisciplinary talents[2]. That is to say, the person who knows not only the basic knowledge of numerical control, such as numerical control programming, process planning, operation and machine commission, but also knows the maintenance and reformation of the machine tool. For the purpose of serving the society better and cultivation more excellent talents, the application-oriented college should reform the cultivation mode.

\section{Reform of Theory Course Teaching}

Scientific and Rational Course Design. Numerical control technology is the integrated products of many different subjects which covering mechanical manufacturing technology, electronic technology, computer technology and many other disciplines. Superior curriculum is the foundation of excellent talents cultivation. Although the knowledge structure of traditional Numerical control talents cultivation is broad, but the students' professional skill is less perfect. To cultivate outstanding Numerical control talents, the knowledge structure must be reformed both in theory teaching and in practical teaching. The knowledge structure is shown in table 1. In order to improving the ability of students to practice and innovative thinking ability, the theoretical class hours are compressed, the practical class hours are increased, the practical class ours account for about 35 percent of the total hours.

Theory Teaching System. The theory teaching system consists of three parts, public basic course, specialized basic course and specialized course respectively. The public basic course is beneficial to 
cultivate the students overall quality and will lay a solid foundation for learning the following courses. According to the internal ration of the course content, the specialized basic course includes three series course, which are electric and electronic, automation control and computer technology. The specialized course pays attention to cultivate the personal comprehensive ability. It embodies the characteristics of the industry automation that is hardware and software combination, strong electricity and weak electricity combination, motion control system and information system combination.

Practical Teaching System. The objective of practical teaching is cultivating the students engineering application ability and integrated innovation ability. Through the course experiment, curriculum design, training, comprehensive practice and graduation design to achieve the cultivation of students ability, in-depth step by step from cognition operation to integrated innovation[3].

Table 1 knowledge structure

\begin{tabular}{|c|c|c|c|}
\hline \multicolumn{2}{|c|}{ Theory teaching } & \multicolumn{2}{|c|}{ Practical teaching } \\
\hline \multirow{8}{*}{$\begin{array}{l}\text { Public basic } \\
\text { course }\end{array}$} & Courses of Foreign & \multirow{8}{*}{$\begin{array}{c}\text { In-class } \\
\text { experiments }\end{array}$} & College Physics \\
\hline & Languages and Cultures & & Experiments \\
\hline & Linear Algebra & & Analog Electronic \\
\hline & & & Technique Experiment \\
\hline & Probability and & & Digital Electronic \\
\hline & Mathematical Statistics & & Technique Experiment \\
\hline & College Physics & & $\begin{array}{l}\text { Experiment of Circuit } \\
\text { Principles }\end{array}$ \\
\hline & $\begin{array}{c}\text { Advanced Mathematics, } \\
\text { etc. }\end{array}$ & & $\begin{array}{l}\text { Practice of Computer } \\
\text { Fundamental Skills }\end{array}$ \\
\hline \multirow{4}{*}{$\begin{array}{l}\text { Engineering } \\
\text { basic course }\end{array}$} & Engineering Drawing & \multirow{4}{*}{ Course design } & NC principle and system \\
\hline & $\begin{array}{l}\text { Analog Electronic } \\
\text { Technique }\end{array}$ & & Electrical control and PLC \\
\hline & Programming Language C & & $\begin{array}{l}\text { Motor drive and motion } \\
\text { control }\end{array}$ \\
\hline & Circuit Principles ,etc. & & $\begin{array}{l}\text { Microprocessor } \\
\text { application }\end{array}$ \\
\hline \multirow{4}{*}{$\begin{array}{l}\text { Specialized basic } \\
\text { course }\end{array}$} & Automatic control theory & \multirow{4}{*}{ Practical training } & CAD \\
\hline & Power electronics & & EDA \\
\hline & mechanical foundation & & Metalworking Practice \\
\hline & computer control technology & & $\begin{array}{l}\text { NC machine tool } \\
\text { operation, etc. }\end{array}$ \\
\hline \multirow{5}{*}{$\begin{array}{l}\text { Specialized core } \\
\text { course }\end{array}$} & NC principle and system & \multirow{5}{*}{ Project training } & $\begin{array}{l}\text { NC system comprehensive } \\
\text { training }\end{array}$ \\
\hline & Motor drive and motion & & NC machine tool electric \\
\hline & control & & $\begin{array}{l}\text { installation and commission } \\
\text { Electronic technology }\end{array}$ \\
\hline & Electrical control and PLC & & comprehensive training \\
\hline & NC machine tool, etc. & & $\begin{array}{c}\text { Embedded system } \\
\text { comprehensive training }\end{array}$ \\
\hline $\begin{array}{c}\text { Specialized } \\
\text { selective course }\end{array}$ & $\begin{array}{l}\text { NC process planning } \\
\text { Intelligent control } \\
\text { Modern control theory } \\
\text { EDA technology, etc. }\end{array}$ & $\begin{array}{l}\text { Graduation } \\
\text { design }\end{array}$ & \\
\hline
\end{tabular}

Innovation of Teaching Method. Based on the traditional teaching methods, new methods of instruction should be adopted.

Inducement Teaching Method. The professional courses are abstract and boring, students feel it very difficult to learn. Many students confuse about what they should learn or what they can do after graduation. So teachers should create an actual problem situation according the course, aiming at 
promoting students' interest in learning. At the beginning of the course, teacher should first introduce the importance of the course, the impact on the follow-up course and the practical application in social work, then present the engineering examples combined with this course. Inducement teaching method can guide the student interest in learning step by step, and can kindle the students' enthusiasm and initiative for study as well. So it will help students master professional knowledge and skills better.

Interactive Teaching. A loose and free study atmosphere is beneficial to improving the students' initiative, independent and creative study. The conventional teaching mode of spoon-feeding students should be changed into students-centered pattern, so the interactive teaching should be adopted. The problem-based learning method and the project-based learning method are widely used in classroom teaching.

Multimedia Teaching. Many courses of Numerical control technique major are abstract and hard to understand. So the traditional teaching approach is not suitable for this situation. For example, traditional drawing geometry teaching depends on compass, ruler and slide show etc. the teaching effect is poor. So it is necessary to make full use of modern teaching facilities and methods, that is to say the multimedia teaching. The key knowledge points, complex mechanical construction figures, etc. are all made multimedia courseware, which can save a lot of time to drawing, and it provides a vivid, stereo, overall learning situation, it is in favor of stimulating students interest in learning.

\section{Strengthen the Training of Practical Skill}

Intensify On-campus Practical Training. In order to improve the students operating ability, the practice teaching must be pay abundant attention, and the practical course rate should be increased. To ensure the continuous and the hierarchy of the practical teaching system, each practical course should be organic unified together[4]. For example, the programming, installation and test, maintenance and repair of numeric control machine tool can be combined together. In addition, aiming at the professional course, such as numerical control principle and system, numerical control process planning and programming, numerical control fault diagnosis etc., rational experiment projects should be designed. The experiment project is divided into 3 classes, operating experiment, designing experiment and comprehensive experiment respectively, from easy to difficult. And the scientific and rational experimental instruction should be compiled also.

Use Numeric Control Simulation Software Effectively. The Numerical control machine tool and $\mathrm{NC}$ system is expensive, the hardware resource of experiment is shortage and can not satisfy the demands of practical training. Using Numerical control simulation software to improve the quality of teaching is a good alternative. There are many kinds of simulation software. For instance, not only the geometry models of cutting tool and the workpiece, but also the geometric models of machine, the kinetic model, the geometric model of fixture and the virtual control panel are all included in one Numerical control machining simulation software, and it can be zoomed, rotated, translated in the visible area. This simulation software can be used in material removal simulation, geometric accuracy test, impact test and machining precision test etc. Thus before operating the actual machine tools, students simulate the experiment project in the simulation software. The using of simulation software improves not only the students interest in learning Numerical control programming, but also improves the safety of actual operation.

Enhance Students Skill Certification Training. In order to effectively improve the students Numerical control skill, enhance their competitiveness when they go into the workplace. More than ten types of certifications are provided to the student, such as GE-FANUC certificate, Siemens training certificate, NC senior, maintenance certificate, PLC designer certificate, ministry of information industry CEAC certificate, etc. Encouraging students to participate in all kinds of professional skill certification training and obtain the corresponding certificate.

Instruction the Students Scientific and Technological Innovation. College students' scientific and technology innovation activities are the needs of the development of times, the utmost power of social improvement and the necessary way of cultivating talents. It benefits to educate and increase 
the fundamental technical ability and creative consciousness and synthesize the fulfillment ability. Based on this platform, the engineering training level and teaching reform is promoted, the college students' engineering practice ability is improved, the cooperation and sense of teamwork, innovative awareness are developed as well. A scientific and technological innovation project is about two years also, by researching, exploring and developing on the subject, the students ability of combining theory and practice is increased, the level to solve practice problems is enhance too. Meanwhile it helps establish good style of study.

Enhance School-enterprise Cooperation. To cultivate excellent talents, it is no enough to only rely on the school. The school and enterprise should share resource and responsibility, train the talents together[5]. The methodology of implementing is divided into three phases. First, learning corporate culture, school can invite entrepreneurs who has a wealth of enterprise management experience to represent corporate rules and corporate knowledge for students. Second, the production flow of one enterprise is divided into several modules according to the post, and draw up different concrete education content of course, then the teachers can guide the students purposely. One professional post is docking with one course, which makes the students adapt to the post quickly after graduating from college. Third, the school and enterprise construct internship base together, which provides students with more opportunities of practicum off campus, and it will develop the employment capacity, and the students will be recognized by society.

\section{Conclusion}

The present social needs a large number of excellent NC talents who possess not only theoretical knowledge but also practical knowledge and skills. So the cultivation of this type talents is becoming an important topic that all levels of schools commonly concern and to explore. As an application-oriented college, it should enhance the course system reform, teaching method reform and teaching content reform continuously, at the same time, the practical link should be strengthen, and the school-enterprise cooperation should be reinforced also. Practice has proved that the students' competitiveness of practical ability, creative ability skill and employability are improved.

\section{References}

[1] Lianfu Yang, Hong sun, The effective use in the process of numerical control technology in mechanical manufacturing, Applied mechanic and materials. Vols. $496-500$ (2014) 1485-1488.

[2] Qu Zhijun, Wang Ronglin, Sun Songli, Wu Xiaohua, Research on cultivation mode of high quality talents based on application oriented college, University Education,(2015)146-147.

[3] Wang Wei, Discuss on numerical control practice and numerical control talents cultivation, Science time, (2009). 229-230.

[4] Chen Zhen, Li Chanyou, Xu Fengying, A probe into practical teaching of scale cultivation of excellent numerical control talents in college, Journal of naming polytechnic, Vols 19, (2014)56-5 8.

[5] Zhang Furong. Study and practice on the close type of cooperation between schools and enterprise in running CNC technology of vocational colleges, China modern education equipment, (2014)88-90. 